Bartın Üniversitesi

Eğitim Fakültesi Dergisi

Cilt 6, Sayı 3, s. 859-877, Ekim 2017

BARTIN - TÜRKIYE

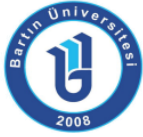

ISSN: 1308-7177
Bartin University

Journal of Faculty of Education

Volume 6, Issue 3, p. 859-877, October 2017

BARTIN - TURKEY

Doi: 10.14686/buefad.325360

\title{
Yabancı Dil Olarak Türkçe Öğretimi Sürecinde Kullanılmak Üzere Geliştirilen Dil Bilgisi Materyallerinin Akademik Başarı ve Yazma Becerisi Üzerindeki Etkisi
}

Muhammet Raşit MEMiş, Arş. Gör., Ondokuz Mayıs Üniversitesi Eğitim Fakültesi, muhammet.memis@omu.edu.tr, ORCID: http://orcid.org/0000-0001-6037-3958

Öz: Son yıllarda Türkçenin yabancı dil olarak öğretimi sürecinde kullanılmak üzere dil becerilerinin geliştirilmesi ve dil bilgisi konularının öğretimi için materyal geliştirme çalışmaları yapılmaktadır. Yapılan çalışmalar incelendiğinde geliştirilen materyallerin gerçek öğretim süreci içerisinde kullanılarak öğretime etki ve yararının tespit edilmemiş olması önemli bir sorun olarak karşımıza çıkmaktadır. Sözü edilen problemi temele alan bu araştırmada yabancı dil olarak Türkçe öğretimi sürecinde kullanılmak üzere geliştirilen materyallerin etkililiğini, yetkinliğini ve başarıya etkisini ortaya çıkarmak amaçlanmaktadır. Çalışma kapsamı açısından daha sınırlandırılmış bir ifadeyle bu araştırmanın amacı, zarflar konusunda animasyonla zenginleştirilmiş materyallerin yabancı dil olarak Türkçe öğrenen bireylerin bu konudaki akademik başarısına etkisi olup olmadığını ve uygulama sonunda öğrencilerin üretim becerilerinden yazma sırasında öğrendiklerini kullanma noktasında gruplar arasında herhangi bir değişime yol açıp açmadığını ortaya koymaktır. Gerçek deneme modellerinden sontest kontrol gruplu model ile desenlenen bu araştırma tesadüfi olarak seçilmiş B1 düzeyindeki iki farklı sınıfta Türkçe öğrenen 16'sı deney, 16'sı kontrol grubu olmak üzere toplam 32 öğrenci ile gerçekleştirilmiştir. Araştırma sonuçlarına göre; araştırmacı tarafından geliştirilen materyallerle zarfları öğrenen öğrencilerin sontest puanlarının öğretim seti ile eğitim alan kontrol grubunun puanlarından daha yüksek olduğu ve gruplar arasında oluşan bu farkın anlamlı bulunduğu ortaya çıkmıştır. Araştırmada elde edilen bir diğer sonuca göre; deney grubunda yer alan öğrencilerin yazılı anlatımlarında kontrol grubu öğrencilerine göre daha çok sayıda zarf kullandıkları belirlenmiştir. Bu sonuçlar deney grubunun eğitim sürecinde kullanılan materyallerin zarflar konusunda akademik başarıyı olumlu yönde etkileyip artırdığını; araştırmacı tarafından geliştirilen öğretim materyaliyle yapılan eğitimin öğrencilerin yazma becerilerinin gelişimine zarfları kullanabilme becerisi bakımından katkı sağladığını göstermektedir.

Anahtar Kelimeler: yabancılara Türkçe öğretimi, dil bilgisi öğretimi, yazma, öğretim materyali, zarflar.

\section{Effects of Grammar Teaching Materials Developed for Teaching Turkish as Foreign Language on Achievement and Writing}

\begin{abstract}
When studies which aim to provide teaching materials needed for both instructing grammar topics and improving language competences in the process of teaching Turkish as foreign language, are analyzed, the most important deficiency is that developed materials have not been tested in terms of functionality, In this research basing upon mentioned problem, it is aimed to find out effectiveness, efficiency and influence on achievement of teaching materials developed for using in teaching Turkish as foreign language. With limited words in the sense of this study's scope, the purpose of this research is to present whether materials enriched with animations in the topic of adverbs have impact on academic achievement of Turkish learners as foreign language or not and variance between groups happens with regard to use of what is learnt in writing competence at the end of implementation or not. This research designed with control group posttest experimental model, carried out 32 (16 experimental, 16 control) Turkish language learners who are in 2 different B1 level class selected randomly. According to research results; posttest scores of learners in experimental group learned adverbs with the materials prepared by researcher are higher than points of students in control group who went with the course book on adverbs and this variation between experimental and control groups is significant. In accordance with another outcome from research; it is detected that learners in experimental group used more adverbs than students in control group as writing. These results show that materials used during instruction of experimental group, affect academic achievement positively in the topic of adverbs and enhance it; instruction via the materials prepared by researcher, contribute to improvement of learners' writing competence in point of ability to use adverbs.
\end{abstract}

Key Words: teaching Turkish as foreign language, grammar teaching, writing, teaching material, adverbs. 


\section{GíRiş}

Dil öğretimi alanında çalışma yapanların özellikle de yabancı dil olarak Türkçe öğretimi üzerine çalışanların üzerinde en çok tartıştıkları konuların başında dil bilgisi öğretiminin gerekli olup olmadığı gelmektedir. Bu konuda, dil bilgisel yapıları örtük biçimde sezdirerek (dolaylı) veya açık biçimde (doğrudan) öğretmek ya da bu kuralların öğretimini yok saymak anlayışına dayanan model ve uygulamalar mevcuttur. Son dönemlerde Türkiye'de dil bilgisi öğretiminin yabancı dil öğretim sürecindeki gerekliliği yönünde bir ortak görüş oluşmuş olsa da öğretim şekli, yöntemi ve yoğunluğu noktasındaki fikir ayrılığı devam etmektedir. Bu doğrultuda Türkçenin yabancı dil olarak öğretiminde dil bilgisi öğretiminin, hedef dilin işleyişini gösteren kuralların anlaşılması ve bu kuralların özellikle üretim becerilerinde kullanılabilmesi amacıyla yapılması gerektiği anlayışı genel kabul görmektedir. Bu görüşe göre; dil bilgisi kurallarının üretim becerilerinden özellikle yazma becerisi içerisinde, yazma becerisinin geliştirilmesine yönelik etkinliklerle iç içe olacak şekilde öğretilmesinin yerinde olacağı ileri sürülmektedir. Türkçe öğretimi sürecinde teorik olarak bu anlayış benimsenmiş görünse de öğretim süreci gözlemlendiğinde birbirinden farklı uygulamaların olduğu göze çarpmaktadır. Uygulamada birlikteliğinin sağlanamaması öğretim sürecinde değişik öğretim setlerinin kullanılmasından, derslerin farklı tecrübe ve eğitim geçmişine sahip okutmanlar tarafından yürütülmesinden ve dil bilgisi kuralları ile üretim becerisi ilişkisini geliştirmeye elverişli olacak şekilde hazırlanmış öğretim materyallerinin eksikliğinden/azlığından kaynaklanmaktadır. Bahsedilen bu hususlardan öğretim materyali azlığı ve eksikliğinin giderilmesine yönelik özellikle yüksek lisans düzeyinde çalışmalar gerçekleştirilmektedir. Bu çalışmalarda araştırmacılar, herhangi bir dil bilgisi konusunun öğretim sürecinde yeterli derece yer almadığı veya öğretim setlerinde ilgili konudaki materyallerin yetersiz kaldığı düşüncesiyle bir ya da birden fazla dil bilgisi konusunun öğretimine yönelik materyal geliştirmişlerdir. Şu ana kadar dil bilgisi konularının öğretimine yönelik üretilen malzemeler kapsamında hazırlanan 12 tez tespit edilmiştir. Bu tezlerde "kiplik (Hacıömeroğlu, 2007), şimdiki zaman (Camkıran, 2007), istek ve emir kipi (Sarıçiyil, 2008), koşullu yapılar (Yolcusoy, 2008), sıfat fiiller (Düzenli, 2008), soru tümceleri (Özgen, 2010), -mış ekinin farklı işlevleri (Ünlücömert, 2010), tanıtsallık belirten sıfat ve zarflar (Öztürk, 2012), zarf fiiller (Kasapoğlu, 2012), -dır biçim birim (Aksu, 2014), birleşik zaman (Korkmaz, 2014) ve zarflar (Memiş, 2014)" konularında öğretim materyali ve etkinlikleri geliştirilmiş ve yabancı dil olarak Türkçe öğretiminde görev alan ilgililerin kullanımına sunulmuştur. Konu başıkları ele alındığında materyal geliştirmek üzere seçilen dil bilgisi konularının genellikle öğrenciler tarafından zor olarak değerlendirilen, okutmanların da öğretim sırasında zorlandığı konular olduğu görülmektedir. Bu araştırmanın uygulama sürecinde kullanılan materyaller de yine bu hususlar gözetilerek seçilmiş olan zarflar konusunda hazırlanmıştır.

Zarf en genel ifadesiyle "bir fiilin, bir sıfatın veya bir zarfın anlamını zaman, yer, ölçü, nitelik, soru kavramları bakımından etkileyen kelime" (TDK, 2011: 2645) şeklinde tanımlanmakta, kimi araştırmacılar tarafından "zarf" (Ergin, 2008, s. 258; Banguoğlu, 1986, s. 372; Bilgegil, 1984, s. 216; Korkmaz, 2009, s. 451) kimileri tarafından ise "belirteç" (Vardar, 2002, s. 35; Gencan, 2001, s. 442; Hengirmen, 1998, s. 160) olarak isimlendirilmektedir. Zarfların tanımlanması ve dil bilgisi konuları arasında konumlandırımasında "ayrı bir sözcük türü, isim soylu sözcüklerin bir alt grubunda görevli bir sözcük türü ve söz dizimsel bir öge" şeklinde üç farklı yaklaşım bulunmaktadır. Bu yaklaşımlardan hareketle Türkiye Türkçesindeki zarfların özellikleri şu şekilde sıralanabilir:

* Zarf görevi yapan kelime ve kelime grupları yüklemi zaman, tarz, sebep, miktar, yön, vasıta ve şart bildirerek tamamlar. Ayrıca sıfatların veya başka zarfların da anlamını etkilemekte kullanılırlar. 
* Zarflardan pek çoğu isim olduğu halde, her isim bir zarf olamamaktadır. İsim olamayan zarfların sayısı ise çok azdır. Bunlar tek başına edat olan zarflar, yani zarf olarak kullanılan edatlardır.

* Zarflar tâbi olan unsur olarak bağlandıkları kelimelerden önce gelirler.

* Zarflar esas itibariyle çekimsiz unsurlardır. İsim oldukları zaman çekim eklerini alır, fakat zarf oldukları zaman hal ve yer bildiren çekim ekleri dışındaki çekim eklerini almazlar.

* İsimler eksiz veya yön, eşitlik, vasıta hali ve diğer bazı hal ekleriyle; fiiller de zarf-fiil ekleriyle cümlede zarf görevi yaparlar.

* Bir cümlede aynı veya ayrı türden birden fazla zarf bulunabilir. Ayrı cinsten zarfların bir arada bulunduğu bir cümlede, genellikle zaman zarfı diğer zarfların önünde yer alır. Miktar bildiren zarflar ise yüklemin hemen yanındadır.

* Bazı zarflar, kendilerinden önceki diğer zarfların açıklayıcısı olabilir.

* Zaman, tarz, sebep, vasıta, miktar, yön ve şart bildiren bütün kelime grupları cümlede zarf görevi yapabilir.

* Cümle tahlillerinde yükleme sorulan nasıl, ne zaman, ne ile, kiminle, hangi şartlarda, kim tarafından, niçin, ne kadar, hangi yöne gibi sorular, zarf ögesini bulmayı kolaylaştırır (Bilgegil, 1984, s. 211-212; Karahan, 2005, s. 32-26; Ergin, 2008, s. 258259; Korkmaz, 2009, s. 451-453; Gülensoy, 2010, s. 580; Eker, 2011, s. 377-378; Karaağaç, 2012, s. 426-429).

Zarflar işlev bakımından ele alındığında sıfatları, diğer zarfları, fiilleri, fiilimsileri ve cümleleri açıklayan, belirten, onların anlamlarını genişleten ya da daraltan bunları yer, zaman, tarz, benzerlik, sebep, sonuç, amaç, derece, azlık-çokluk ve şart bakımından niteleyerek anlamın daha net ortaya çıkmasında görev yapan kelime veya kelime gruplarıdır (Turan, 1998, s. 301-305). Zarflar anlama dayalı bir dil bilgisi konusu olduğu için cümlenin vazgeçilmez unsurlarındandır. Yukarıda belirtildiği üzere zarflar cümledeki anlamı neredeyse her yönüyle açıklayıp belirgin hale getirdiği için iletişimin sağıklı ve etkili olarak gerçekleşmesinde önemli rol üstlenirler. Bu yönüyle de zarfların, bilhassa iletişim aracı olarak kullanılan dilin bu işlevini yerine getirmesinde kilit bir görevi olduğu söylenebilir. Günümüzde yabancı dil öğretiminin anlama dayalı ve iletişim odaklı yapılması gerektiği; dil bilgisi konularının da yine bu çerçevede seçilip öğretime dâhil edilmesinin yerinde olacağı kabul edilmektedir. Bu açıdan bakıldığında zarfların yabancı dil öğretiminde yer almasının, iletişimde bulunan bireyler arasında hem anlamın netleşmesine yardım edeceği hem de dil öğrenenlerin kelime hazinesinin genişlemesine katkı sağlayıp dil becerilerinin gelişimine doğrudan ve dolaylı olarak olumlu yönde etki edeceği değerlendirilmektedir. Başka bir ifadeyle zarflar yabancı dil öğretimindeki gerekliliği, yararı ve yabancı dil öğrenenlerin dil becerilerinin geliştirilmesi açısından ele alındığında, kelime hazinesine yeni bir sözcük olarak katılan her zarf, öğrencinin okuduğunu ve dinlediğini daha iyi anlamasına, özellikle de okurken öğrenmiş olduğu zarfların cümlenin anlamına yaptığı etkiyi ve anlamda oluşturduğu değişikliği daha iyi görebilmesine önemli katkı sağlayacaktır. Ayrıca öğrenilen her bir zarf öğrencinin, hem konuşma hem yazma sırasında, özellikle de bir metin oluştururken, anlatılmak istenen durum veya olayla ilgili daha kapsamlı, daha çok bilgi ihtiva eden, daha uzun ve karmaşık cümleler kurabilmesine yardımcı olacaktır.

Yukarıda ifade edilen bilgilerden hareketle zarflar konusunun yabancı dil öğretim sürecinde mutlaka yer alması gerektiği düşünülmektedir. Bu düşünceden hareketle Türkçenin yabancı dil olarak öğretilmesi sürecinde kullanılan ders kitapları incelenmiş, zarfların öğretimde yer aldığı fakat öğretim etkinliklerinin hem nicelik hem nitelik bakımından yeterli seviyede olmadığı görülmüştür. Bu setlerde genellikle zarfların öğretimine kısaca yer ayrılmış, zarfların işlevlerini ortaya çıkararak öğrencide farkındalık oluşturacak ve dil becerilerine katkı sağlayacak yetkinlikte bir etkinliğe yer verilmemiştir. Bu yetersizlik diğer dil bilgisi konularında da zaman 
zaman kendini göstermekte, bu nedenle de yukarıda değinildiği üzere araştırmacıları yabancı dil olarak Türkçenin öğretimi için dil bilgisi materyali geliştirmeye sevk etmektedir. Sözü edilen materyal geliştirme çalışmaları incelendiğinde göze çarpan en önemli eksiklik ise geliştirilen dil bilgisi öğretim materyallerinin işlevselliğinin denenmemiş olması başka bir deyişle materyallerin gerçek yabancı dil öğretim süreci içerisinde kullanılarak etkisinin tespit edilmemiş olmasıdır. Bahsedilen bu problemi temele alan bu araştırmada yabancı dil olarak Türkçe öğretimi sürecinde kullanılmak üzere geliştirilen materyallerin etkililiğini, yetkinliğini ve başarıya etkisini ortaya çıkarmak hedeflenmektedir. Çalışma kapsamı açısından daha sınırlandırılmış bir ifadeyle bu araştırmanın amacı, zarflar konusunda animasyonla zenginleştirilmiş materyallerin yabancı dil olarak Türkçe öğrenen bireylerin bu konudaki akademik başarısına etkisi olup olmadığını ve uygulama sonunda öğrencilerin üretim becerilerinden yazma sırasında öğrendiklerini kullanma noktasında gruplar arasında herhangi bir değişime yol açıp açmadığını ortaya koymaktır. Bu temel amaç doğrultusunda araştırmada şu sorulara cevap aranmıştır:

* Deney ve kontrol grubu öğrencilerinin sontest toplam puan ortalamaları arasında anlamlı bir fark var mıdır?

* Uygulama sürecinin sonunda deney ve kontrol grubu öğrencilerinin yazılı anlatımlarında kullandıkları zarf sayısı bakımından anlamlı bir fark var mıdır?

* Deney ve kontrol grubundaki öğrencilerin sıklıkla kullandıkları zarflar nelerdir?

\section{YÖNTEM}

\subsection{Araştırmanın Deseni}

$\mathrm{Bu}$ araştırma gerçek deneme modellerinden sontest kontrol gruplu model ile desenlenmiştir. Bu desende biri deney biri kontrol grubu olmak üzere yansız atama ile oluşturulan iki grup bulunur ve bu gruplara yalnızca sontest uygulanır. Çoğu denemelerde ön testin uygulanması ya olanaksız ya da gereksizdir (Karasar, 2010: 98). Bu çalışmanın uygulanacağı grubun araştırılan konudaki önbilgileri ve yeterlilikleri düşünüldüğünde, çalışma grubundaki öğrencilerin bulundukları düzeyde hem zarfların Türkçedeki işlevlerini henüz bilmiyor olması hem de zarf görevinde kullanılan sözcüklerin kelime hazinelerinde bulunmaması nedeniyle uygulama öncesinde bir ön test yapmak mantıksız ve gereksizdir. Aşağıdaki çalışma boyunca izlenecek aşamaların simgesel görünümü sunulmuştur:

Tablo 1: Çalışmanın Simgesel Görünümü

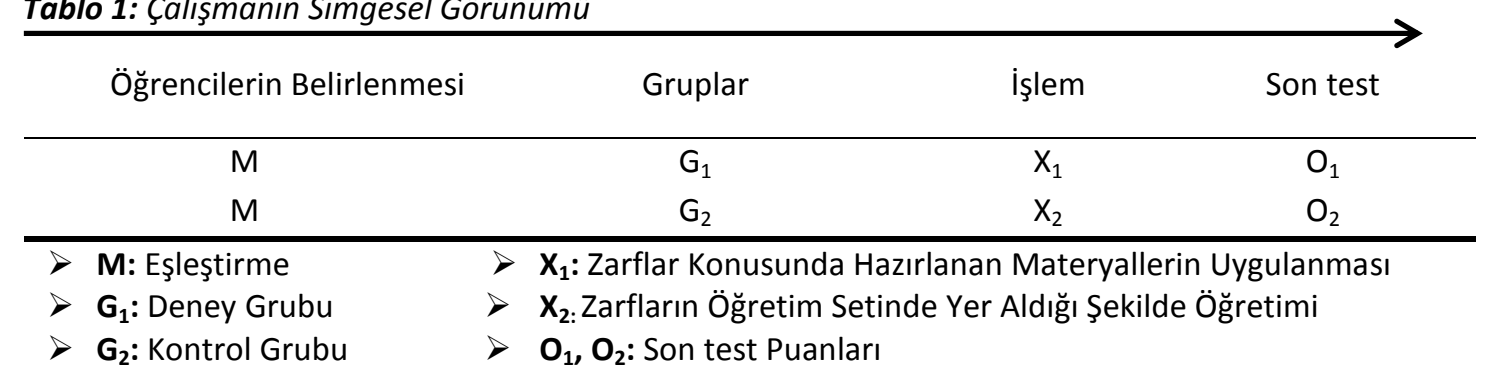

\section{2. Çalışma Grubu}

Bu çalışma, 2017 yılında Türkiye'de yabancı dil olarak Türkçe öğrenen ve araştırmanın yapıldığı tarihte B1 düzeyinde bulunan dil sınıfları içerisinden tesadüfi olarak seçilmiş iki farklı sınıftaki öğrencilerle yürütülmüştür. Araştırmanın çalışma grubu $16^{\prime}$ sı deney, 16 'sı kontrol grubu olmak üzere toplam 32 öğrenciden oluşmaktadır. Çalışma grubuyla ilgili diğer bilgiler aşağıdaki tabloda sunulmuştur: 
Tablo 2: Çalışma grubuna ait bilgiler

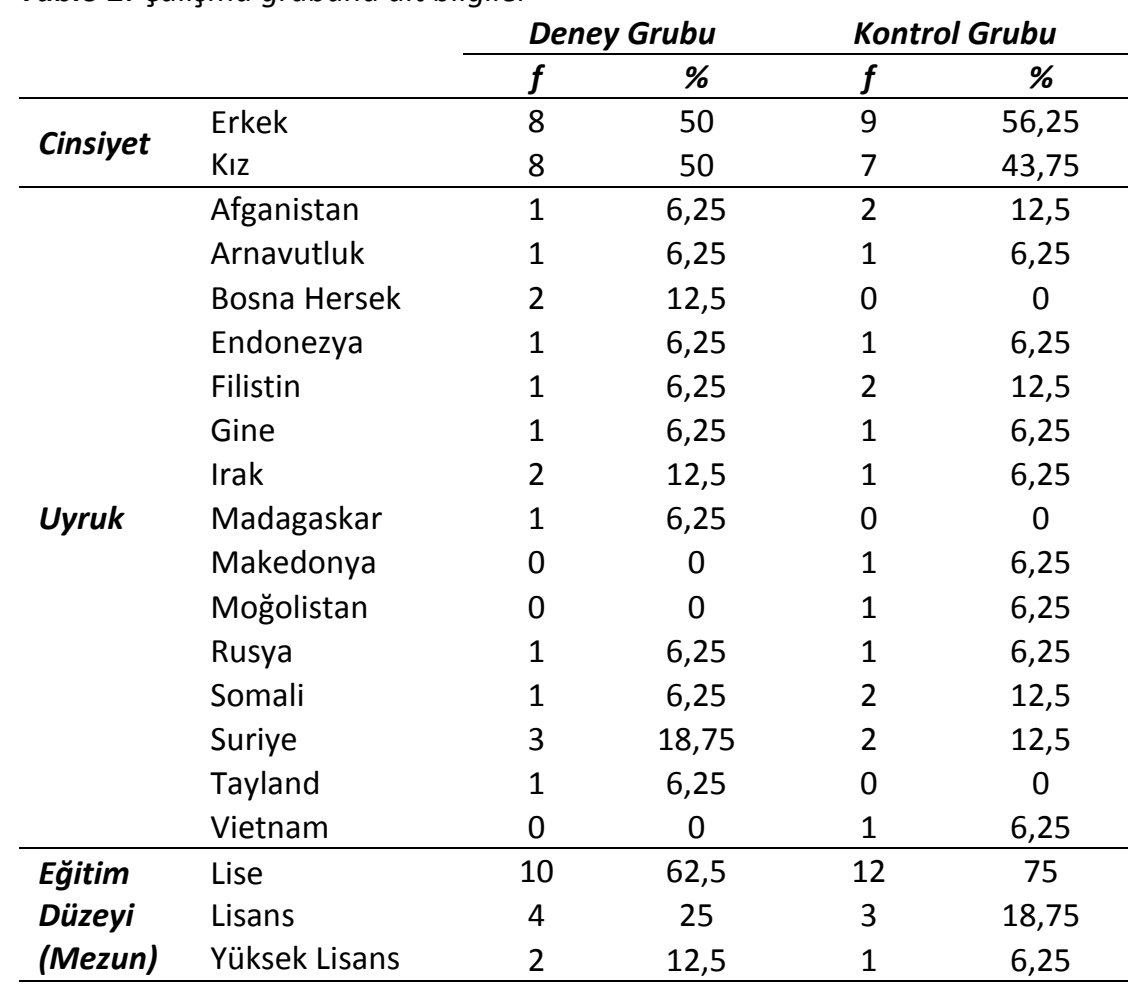

Çalışma grubunda yer alan öğrencilerin $15^{\prime} \mathrm{i}$ kız 17 'si erkek öğrenciden oluşmaktadır. Deney ve kontrol grubu mevcutlarının eşit ve bu gruplardaki öğrenci sayısının cinsiyete göre birbirine çok yakın olmasının daha isabetli bulguların elde edilmesine katkı sağladığı düşünülmektedir. Araştırmaya katılan yabancı öğrencilerin uyrukları incelendiğinde çalışma grubunda 15 farklı ülkeden öğrenci bulunduğu görülmektedir. Çalışma grubunda farklı dil, kültür ve öğrenim geçmişinden bireylerin olması araştırma sonuçlarının genellenebilirliğini artırmaktadır. Son olarak tabloda görüldüğü üzere ortak noktası üniversite eğitimi olan çalışma grubu öğrencilerinin 22'si lisans, 7'si yüksek lisans ve 3'ü doktora eğitimi için Türkçe öğrenmektedir.

\section{3. Çalışmada Kullanılan Öğretim Malzemesi ve Uygulama Süreci}

$\mathrm{Bu}$ araştırmada deney grubu olarak belirlenen sınıfta gerçekleştirilen öğretimde araştırmacı tarafından hazırlanan materyaller kullanılmıştır. Zarflar konusunda geliştirilen bu materyaller yabancı dil olarak Türkçe öğretimindeki materyal eksikliğinin giderilmesine katkı sağlamak amacıyla bilgisayar destekli olarak hazırlanmıştır. Hazırlanan öğretim malzemesinin özgünlük açısından taşıdığı en önemli özelliklerden biri zarfların anlamlarının açıklanmasında kullanılan animasyonlu materyaller içermesidir. Zarflar konusunda geliştirilen öğretim materyalleri "Zarf Nedir? , Sıfat-Zarf Ayrımı, Sıfatların Zarf Olarak Kullanımı, Sıfatlardan Zarf Yapımı, Zarfların Cümledeki Yeri, Zarf Türleri (Zaman, Yer-Yön, Miktar, Durum Ve Soru Zarfları)" şeklinde bölümlere ayrılmıştır. Her bölümde işlenen konuyla ilgili kural ya da kurallar basitleştirililerek verilmiş, görselleştirilmiş ve örnek cümlelerle desteklenmiştir. Her bölümün sonunda da öğretilenlerin pekiştirilmesi amacıyla alıştırmalar verilmiştir. Bu materyaller kullanılarak deney grubundaki öğrencilerle B1 kurunun dil bilgisi dersleri kapsamında toplamda 8 saatlik bir uygulama gerçekleştirilmiş ve uygulama araştırmacının kendisi tarafından yürütülmüştür. Aşağıda öğretim sürecinde kullanılan animasyonlardan örnek bir ekran görüntüsü sunulmuştur: 
Örnek Ekran Görüntüsü 1: “Yukarı” zarfı

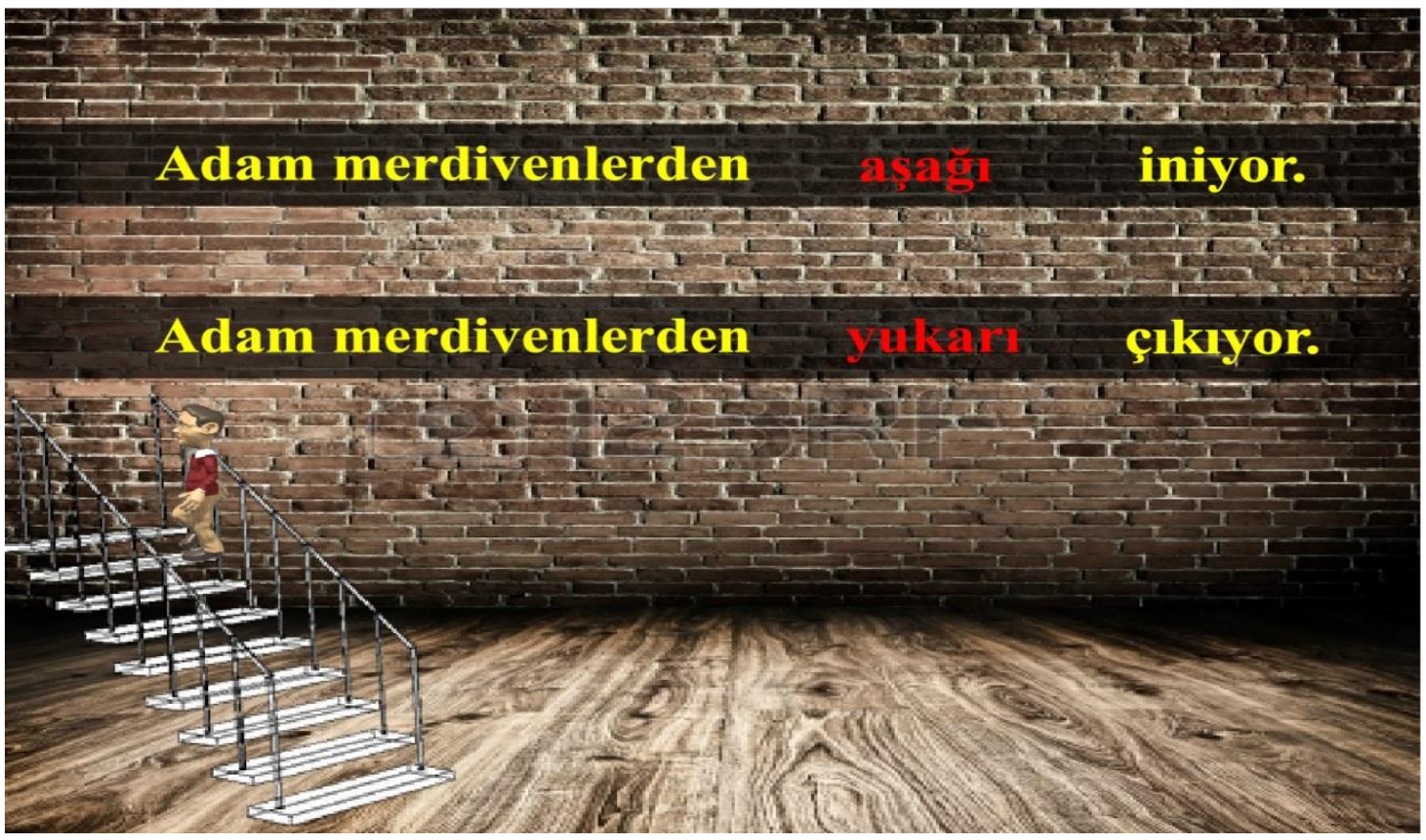

Örnek Ekran Görüntüsü 2: "Aşağı" zarfı

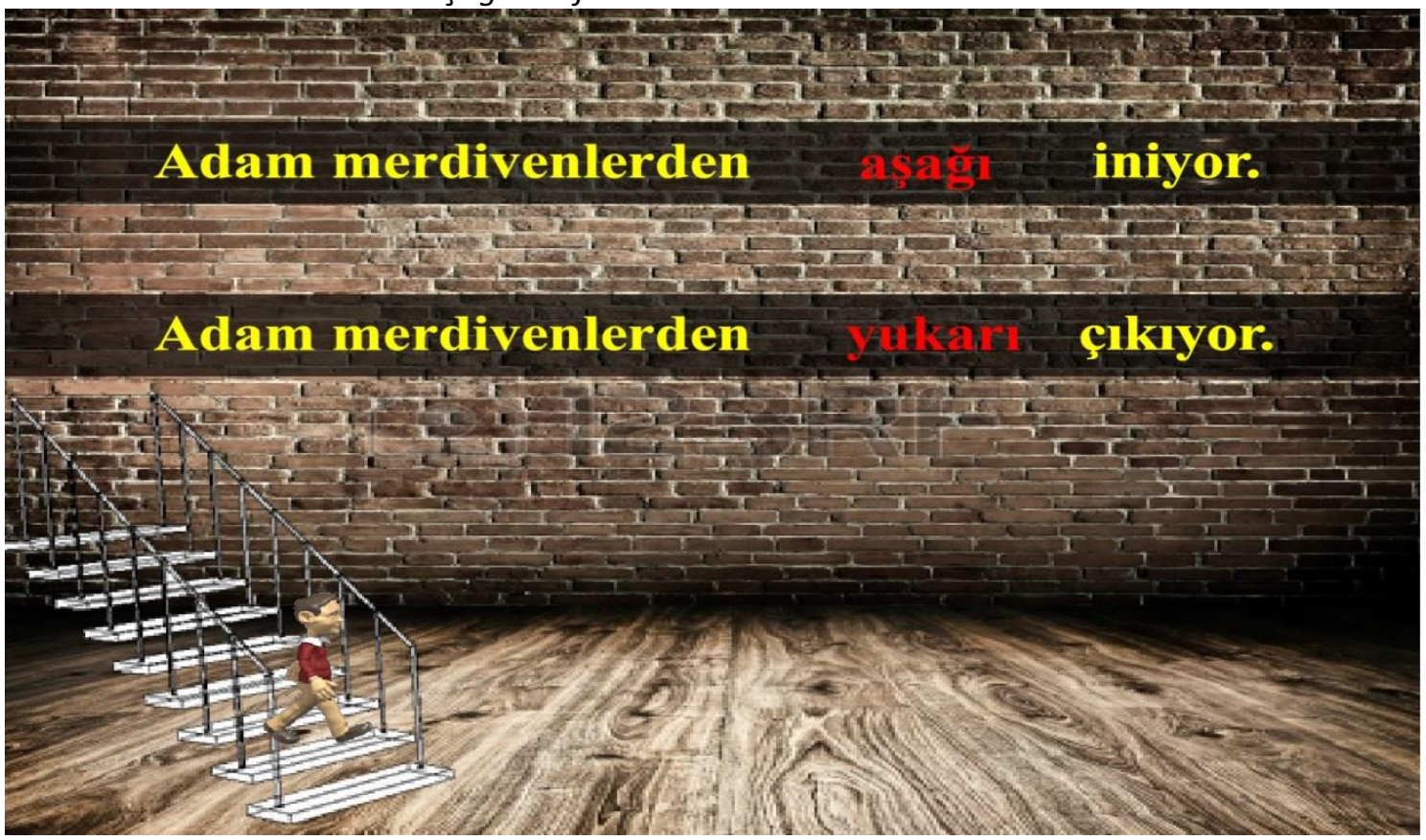

Yukarıda ekran görüntüleri verilen örnek animasyon yer-yön zarflarının öğretimi kapsamında hazırlanmıştır. Bu animasyonda zarf görevinde kullanılan "yukarı" kelimesine tıklandığında görüntüdeki karakter ekranın sağ tarafından hareketlenerek merdivenlerden yukarıya doğru çıkmaktadır. Aynı şekilde "aşağı" kelimesine tıklandığında da karakter merdivenlerden aşağıya doğru inmeye başlamaktadır. Örnekte görüldüğü üzere öğretilmek ve vurgulanmak istenen kelimeler kırmızı ile yazılmıştır. Ekranda yer alan cümledeki diğer kelimelere tıklandığında karakter hareket etmemekte, yalnızca kırmızı ile yazılı olan "aşağı" ve "yukarı" sözcüklerine tıklandığında görüntü akmaya başlamaktadır. Bu özelliklerin öğrencinin dikkatini çekerek öğretim amacının gerçekleşmesine katkı sağladığı düşünülmektedir. 


\subsection{Veri Toplama Araçları}

Öğrencilerin zarflar konusundaki akademik başarısını belirlemek için araştırma amacına uygun olacak şekilde alanında uzman ilgililerin desteğiyle araştırmacı tarafından zarflar konusunda bir başarı testi hazırlanmıştır. Bu başarı testinin geliştirilmesi aşağıdaki aşamalarda gerçekleştirilmiştir:

Öncelikle zarflar konusunda bir alanyazın taraması yapılmış (Karahan, 2005; Korkmaz, 2009; Ergin, 2008; Gülensoy; 2010, Karaağaç, 2012) ve sıklıkla kullanılan zarflar belirlenmeye çalışılmıştır. Daha sonra Türkçenin yabancı dil olarak öğretimi sürecinde kullanılan öğretim setleri zarflar bakımından incelenmiş ve zarf konusu kapsamında öğretilen kelimeler ile alanyazın taramasında belirlenen kelimeler karşılaştırılarak bu iki kaynaktan elde edilen sözcüklerden 250 kelimelik bir derlem oluşturulmuştur. Başarı testinde ölçülen kelimeler bu derlem içerisinden seçilmiştir.

Başarı testinde ölçülecek kazanımların belirlenmesi için Türkiye Türkçesindeki zarf konusu dil bilgisel açıdan derinlemesine araştırılmış, bu konunun ana dili eğitimi ve yabancı dil öğretiminde nasıl ele alındığı incelenerek yabancı dil olarak Türkçe öğrenen bir bireyin zarflar konusunda sahip olması gerektiği düşünülen ölçülebilir kazanımlar oluşturulmuştur. Daha sonra bu kazanımlar uzman görüşüne sunulmuş ve uzmanlardan gelen geri dönütlere göre kazanımlara son şekli verilmiştir. Aşağıdaki tabloda ilgili kazanımlar ve başarı testinde ölçülen zarfların listesi sunulmuştur:

Tablo 3: Zarflar Konusunda Geliştirilen Başarı Testinde Ölçülen Kazanımlar ve Zarflar

1. Sıfat ile zarfları işlev bakımından ayırt edebilir.

2. Sıfatları zarf görevinde kullanabilir.

3. Sıfatları "sıfat + CA" eki ve "sıfat + bir şekilde" kalıbı yardımıyla zarf görevinde kullanabilir.

4. Zarfların cümle içindeki yerini ve cümle içinde kullanıldığı yere göre kazandığı anlamları bilir.

5. Sıfat ve zarf görevinde kullanılan kelimeleri bilir ve amacına uygun bir şekilde kullanır.

6. Fiilleri durum yönünden niteleyen kelimeleri bilir ve bu kelimeleri amacına uygun biçimde kullanır.

7. Fiilleri zaman yönünden niteleyen kelimeleri bilir ve bu kelimeleri amacına uygun biçimde kullanır.

8. Fiilleri yer-yön bakımından niteleyen kelimeleri bilir ve bu kelimeleri amacına uygun biçimde kullanır.

9. Fiilleri miktar yönünden niteleyen kelimeleri bilir ve bu kelimeleri amacına uygun biçimde kullanır.

10. Soru zarflarının işlevini ile soru zarfı olarak kullanılan kelimelerin anlamını bilir ve soru zarflarını amacına uygun biçimde kullanır.

Güzel, Hızlı, Yeni, Geç, Tekrar, Mutlu, Sessizce, Sessiz bir şekilde, Kötü bir şekilde, Kolayca, Açıkça, Yavaşça, Yavaş bir şekilde, Uzunca

Aniden, Çabucak, Hep birlikte, lyice, Yine, Sadece

Erken, Sonunda, Henüz, Sık sık, Artık, Bir süre, Daima

Ileri, Dışarı, Uzak, Yukarı

Biraz, Oldukça, Son derece, Epey, Tamamen

Ne kadar, Neyle, Nereye, Hangi yöne, Ne tarafa, Kiminle, Nasıl, Neden, Ne biçim, Nerede, Kim, Ne

TOPLAM KELIME SAYISI: 48

Uzman görüşü neticesinde belirlenen 10 adet kazanımın her biri için 4 soru oluşturulmuş ve hazırlanan 40 soruluk deneme formunun kapsam ve görünüş geçerliliğini belirlemek için ilgili test taslağı Türkçe eğitimi alanında doktorasını tamamlamış ve yabancı dil 
olarak Türkçe öğretimi sürecinde görev almış 6 öğretim üyesine "soru-kazanım, soru-cevap, soru-içerik, soru-dil bilgisi, soru-dil düzeyi, soru-yazım tekniği" uyumu bakımından inceletilmiştir. Sorular üzerinde yapılan değerlendirmeler sonunda eksik veya düzeltilmesinde fayda görülen sorular öneriler doğrultusunda revize edilerek başarı testi uygulama öncesi geçerlilik ve güvenirlik çalışması için hazır hale getirilmiştir.

Yukarıdaki aşamalardan geçerek hazırlanan başarı testinin asıl uygulama öncesinde ölçme değerlendirme ilkeleri açısından uygunluğunun tespit edilmesi için geçerlilik-güvenirlik çalışmasına tabi tutulmuştur. Denemelik formlar Türkiye genelinde farklı kurumlarda yabancı dil olarak Türkçe öğrenen C1 seviyesine gelmiş olan 108 öğrenciye uygulanmıştır. Bu uygulamada elde edilen veriler doğru cevaplar "1", yanlış cevaplar " 0 " şeklinde puanlanarak bilgisayar ortamına aktarılmış, testin ve testi oluşturan maddelerin analizine geçilmiştir. Yapılan analizler neticesinde öncelikle madde ayırt edicilik indeksi $0.30^{\prime}$ un altında olan 7 soru testten çıkarılmıştır. Daha sonra uygulama, puanlama ve analiz kolaylığı sağlayacağı gerekçesiyle madde ayırt edicilik indeksi 0.30 'a en yakın olan 3 soru daha testten çıkarılmış ve uygulamada kullanılacak başarı testinde 30 adet soru bırakılmıştır. Son şekli verilen testin ve maddelerin analiz sonuçları aşağıdaki tabloda verilmiştir:

Tablo 4: Zarflar Konusunda Hazırlanan Başarı Testi Madde Analizi Sonuçları

\begin{tabular}{ccccccccc}
\hline Soru & $\mathbf{P j}$ & $\mathbf{R j}$ & Soru & $\mathbf{P j}$ & $\mathbf{R j}$ & Soru & $\mathbf{P j}$ & $\mathbf{R j}$ \\
\hline $\mathbf{1}$ & 0,74 & 0,37 & $\mathbf{1 1}$ & 0,46 & 0,48 & $\mathbf{2 1}$ & 0,59 & 0,52 \\
$\mathbf{2}$ & 0,72 & 0,33 & $\mathbf{1 2}$ & 0,59 & 0,52 & $\mathbf{2 2}$ & 0,54 & 0,70 \\
$\mathbf{3}$ & 0,69 & 0,41 & $\mathbf{1 3}$ & 0,48 & 0,44 & $\mathbf{2 3}$ & 0,46 & 0,48 \\
$\mathbf{4}$ & 0,59 & 0,59 & $\mathbf{1 4}$ & 0,52 & 0,74 & $\mathbf{2 4}$ & 0,59 & 0,37 \\
$\mathbf{5}$ & 0,57 & 0,56 & $\mathbf{1 5}$ & 0,43 & 0,41 & $\mathbf{2 5}$ & 0,48 & 0,44 \\
$\mathbf{6}$ & 0,52 & 0,67 & $\mathbf{1 6}$ & 0,44 & 0,59 & $\mathbf{2 6}$ & 0,61 & 0,41 \\
$\mathbf{7}$ & 0,61 & 0,41 & $\mathbf{1 7}$ & 0,39 & 0,48 & $\mathbf{2 7}$ & 0,46 & 0,48 \\
$\mathbf{8}$ & 0,54 & 0,63 & $\mathbf{1 8}$ & 0,41 & 0,52 & $\mathbf{2 8}$ & 0,44 & 0,52 \\
$\mathbf{9}$ & 0,56 & 0,44 & $\mathbf{1 9}$ & 0,39 & 0,41 & $\mathbf{2 9}$ & 0,59 & 0,44 \\
$\mathbf{1 0}$ & 0,59 & 0,37 & $\mathbf{2 0}$ & 0,54 & 0,56 & $\mathbf{3 0}$ & 0,65 & 0,41 \\
\hline
\end{tabular}

Tablo 5: Zarflar Konusunda Hazırlanan Başarı Testinin Genel Analiz Sonuçları

\begin{tabular}{cccccc}
\hline $\begin{array}{c}\text { Aritmetik } \\
\text { Ortalama }\end{array}$ & $\begin{array}{c}\text { Ortalama } \\
\text { Güçlük }\end{array}$ & $\begin{array}{c}\text { Ortalama } \\
\text { Ayırt Edicilik }\end{array}$ & $\begin{array}{c}\text { Standart } \\
\text { Sapma }\end{array}$ & Varyans & Kr-20 \\
\hline 16,204 & 0,540 & 0,638 & 7,957 & 63,310 & 0,917 \\
\hline
\end{tabular}

Başarı testinin genel analiz sonuçlarına bakıldığında testin aritmetik ortalaması 16.2, ortalama güçlügü 0.54 , ortalama ayırt ediciliği 0.64 olarak tespit edilmiştir. Testin güvenirlik değeri ise 0.92 şeklinde belirlenmiştir. Bu sonuçlara göre; geliştirilen akademik başarı testinin orta güçlükte, ayırt ediciliği ve güvenirliği oldukça yüksek bir test olduğu görülmektedir.

$\mathrm{Bu}$ araştırma çerçevesinde, öğretim süreci sonunda öğrencilerin zarfları ne ölçüde kullanabildiklerini tespit etmek amacıyla deney ve kontrol grubundaki öğrencilerin B1 kurunun sonunda yapılan yazma becerisi sınavındaki yazıı anlatım kâğıtları da veri toplama aracı olarak kullanılmıştır. Bu veri toplama aracı ile öğrencilere hiçbir yönlendirme yapılmadığında biri geliştirilen öğretim materyalleri ile diğeri öğretim setinde yer verildiği şekilde zarfları öğrenmiş iki grup arasında üretim becerisi bakımından anlamlı bir fark olup olmadığını belirlemek amaçlanmıştır. İncelenen yazılı anlatım kâğıtlarında deney ve kontrol grubundaki öğrencilerin hangi zarfları ne sıklıkla kullandıkları incelenmiş ve veriler nicel bir yaklaşımla karşılaştırılmıştır. 


\subsection{Verilerin Analizi}

Araştırmanın amaçları doğrultusunda veri toplama araçlarıyla elde edilen verileri istatiksel olarak analiz edebilmek için kodlanarak bilgisayar ortamına aktarılmış ve bu veriler SPSS 21 (The Statistical Packet for The Social Sciences) isimli program kullanılarak çözümlenmiştir. Deney ve kontrol gruplarının sontest puanları arasında anlamlı bir farkın olup olmadığını belirlenmesinde ilişkisiz örneklemler için $t$ testinden, etki büyüklüğünün ölçülmesinde Cohen's d ve Hedges's g hesaplamalarından faydalanılııştır.

\section{BULGULAR}

Nicel yöntemlerden son test kontrol gruplu modelin kullanıldığı bu araştırmada bilgisayar destekli hazırlanan zarflar konusundaki dil bilgisi öğretim materyallerinin yabancı dil olarak Türkçe öğrenenlerin akademik başarısına etkisi ve anlatma becerilerinden yazma becerisine katkısı belirlenmeye çalışılmıştır. Bu amaç doğrultusunda geliştirilen akademik başarı testi ve çalışmaya katılan öğrencilere ait kur sonu yazma becerisi sınavı yazılı anlatım kâğıtları aşağıdaki bulguların elde edilmesinde araç olarak kullanılmıştır.

Öncelikle veri toplama aracı olarak kullanılan akademik başarı testinden elde edilen sonuçları analiz edebilmek için bu verilerin normal bir dağılım gösterip göstermediğini belirlemek üzere normallik testi yapılmıştır. Elde edilen sonuç aşağıdaki tabloda verilmiştir:

Tablo 6: Deney ve Kontrol Grubundaki Öğrencilerin Elde Ettikleri Puanlarının Normallik Değerleri

\begin{tabular}{lccccc}
\hline \multirow{2}{*}{ Gruplar } & & \multicolumn{4}{c}{ Shapiro-Wilk } \\
\cline { 3 - 6 } & $\mathbf{N}$ & \multicolumn{2}{c}{ Akademik Başarı Testi } & \multicolumn{2}{c}{ Yazılı Anlatım Kâğıtları } \\
& & $t$ & $p$ & $t$ & $P$ \\
\hline Deney & 16 &, 959 &, 647 &, 967 &, 794 \\
Kontrol & 16 &, 983 &, 983 &, 975 &,
\end{tabular}

Tablo incelendiğinde yapılan Shapiro-Wilk testi sonucuna göre deney $(0.647>0.05)$ / $(0.794>0.05)$ ve kontrol $(0.983>0.05)$ / $(0.916>0.05)$ grubundaki öğrencilerin hem zarflar konusunda hazırlanan akademik başarı testinden elde ettikleri sontest puanlarının hem de kur sonundaki sınavda toplanan yazılı anlatım kâğıtlarında kullandıkları toplam zarf sayılarının \%95 güven aralığında normal dağılım gösterdiği görülmüştür. Bu analiz neticesinde sontest puanları gruplara göre normal dağılım gösterdiğinden verilerin incelenmesinde parametrik testlerden bağımsız $t$ testi'nin kullanılmasına karar verilmiştir.

\subsection{Birinci Amaca ilişkin Bulgular}

Zarflar konusunda hazırlanan ve uygulanan öğretim materyalleri ve dil öğretim seti aracılığıyla yapılan öğretimin öğrencinin bu konudaki akademik başarısı üzerinde etkisini karşılaştırmak amacıyla grupların sontest puanları bağımsız değişkenli $t$ testi ile karşılaştırılmıştır. Bu doğrultuda "deney ve kontrol grubu öğrencilerinin sontest toplam puan ortalamaları arasında anlamlı bir fark var mıdır?" sorusuna yanıt aranmıştır. Yapılan analiz sonuçları aşağıdaki tabloda sunulmuştur:

Tablo 7: Deney ve Kontrol Grubundaki Öğrencilerin Sontest Puanlarına Illişkin T-Testi Sonuçları

\begin{tabular}{cccccccc}
\hline Grup & $\mathbf{N}$ & $\overline{\boldsymbol{X}}$ & Ss & Sd & $\overline{\boldsymbol{X}} \mathbf{f}$ & $\mathbf{T}$ & $\mathbf{P}$ \\
\hline Deney & 16 & 21.81 & 3.88 & 30 & 5.25 & 3.77 & $.01^{*}$ \\
Kontrol & 16 & 16.56 & 3.98 & & & & \\
\hline
\end{tabular}

$* \mathrm{p}<0.05$ 
Tabloda görüldüğg̈ gibi deney grubunda yer alan öğrencilerin sontest başarı puanlarının aritmetik ortalaması 21.81, kontrol grubundaki öğrencilerin ortalama puanları ise 16.56 'dır. Deney ve kontrol grupları arasında 5.25 puanlık bir fark oluşmuştur. Bu durumda deney grubunun kontrol grubuna göre zarflar konusundaki başarı testinden daha yüksek bir puan başarısı elde ettiği söylenebilir. Bu başarının istatiksel açıdan anlamlı olup olmadığını görmek için yapılan t testi sonucuna göre iki grup arasında anlamlı bir farklılığın bulunduğu tespit edilmiştir $(0.01<0.05)$. Başka bir ifadeyle araştırmacı tarafından geliştirilen öğretim materyalleriyle zarfları öğrenen öğrencilerin dil öğretim setiyle zarfları öğrenenlere göre daha yüksek bir akademik başarı sağladıkları görülmektedir. Bu sonucun aynı zamanda öğretim materyallerinin etkinliğini/yetkinliğini de ortaya koyduğu söylenebilir. Yapılan $t$ testi sonucunda deney ve kontrol grupları arasında ortaya çıkan anlamlı farklılığın akademik başarı üzerindeki etkisinin ne ölçüde olduğuna karar verebilmek için etki büyüklüğünün belirlenmesinde kullanılan Cohen's d ve Hedges' g değerleri hesaplanmıştır. Bu değerlerinin yorumlanmasında kullanılan tablo aşağıda yer almaktadır. Etki büyüklüğü değerlerinin yorumlanması için oluşturulan tablo Cohen (1988), Hopkins (1997) ve Hedges (1981) tarafından yapılan çalışmalardan yararlanılarak hazırlanmıştır.

Tablo 8: Etki Büyüklüğü Değerlerinin Yorumlanmasında Kullanılan Ölçekler

\begin{tabular}{cl}
\hline $\mathbf{d}$ & $\mathbf{g}$ \\
$(0>\mathrm{d}<2)$ & $(0>\mathrm{g}<2)$ \\
$\mathrm{d} \leq .20 \sim$ Küçük & $\mathrm{g} \leq .20 \sim$ Küçük \\
$\mathrm{d} \leq .50 \sim$ Orta & $\mathrm{g} \leq .50 \sim$ Orta \\
$\mathrm{d} \leq .80 \sim$ Büyük & $\mathrm{g} \leq .80 \sim$ Büyük \\
$\mathrm{d}>.80 \sim$ Çok Büyük & $\mathrm{g}>.80 \sim$ Çok Büyük \\
\hline
\end{tabular}

Deney ve kontrol grubu arasında ortaya çıkan istatiksel açıdan anlamlı farklılı̆ın etki büyüklüğü hesaplamaları sonucunda $d: 1.33, g: 1.30$ olarak tespit edilmiştir. Hesaplanan etki büyüklüğü değerlerine göre zarflar konusunda gerçekleştirilen deneysel işlemin grupların ortalamaları arasındaki fark üzerinde "çok büyük" etkisinin olduğu belirlenmiştir. Bu sonuç geliştirilen materyallerle yapılan öğretimin öğrencilerin başarısı üzerindeki etkisinin oldukça güçlü ve önemli olduğunu göstermektedir.

\section{2. İkinci Amaca ỉişskin Bulgular}

Bu araştırma kapsamında, iki farklı öğretim materyali aracılığıyla zarfları öğrenen deney ve kontrol grubu öğrencilerinin öğrendiklerini yazma becerisinde ne ölçüde kullandıklarını tespit etmek ve bu iki grup arasında herhangi bir farklılığın oluşup oluşmadığını, oluştuysa bu farkın anlamlı olup olmadığını belirlemek hedeflenmiştir. Bu doğrultuda "Uygulama sürecinin sonunda deney ve kontrol grubu ögrencilerinin yazılı anlatımlarında kullandıkları zarf sayısı bakımından anlamlı bir fark var mıdır?" sorusuna cevap aranmıştır. Yapılan analiz sonuçları aşağıdaki tabloda verilmiştir:

Tablo 9: Deney ve Kontrol Grubundaki Öğrencilerin Kullandıkları Zarf Sayısına Illişkin T-Testi Sonuçları

\begin{tabular}{cccccccc}
\hline Grup & $\mathbf{N}$ & $\overline{\boldsymbol{X}}$ & Ss & Sd & $\overline{\boldsymbol{X}} \mathbf{f}$ & $\mathbf{T}$ & $\mathbf{P}$ \\
\hline Deney & 16 & 12.75 & 2.41 & 30 & 4.50 & 5.85 & $.00^{*}$ \\
Kontrol & 16 & 8.25 & 1.91 & & & & \\
\hline
\end{tabular}

$* \mathrm{p}<0.05$

Tabloda görüldüğü üzere deney grubunda yer alan öğrencilerin kullandıkları zarf sayılarının ortalaması 12.75 , kontrol grubundaki öğrencilerin ise $8.25^{\prime}$ tir. İki grup arasında 4.5 puanlık bir fark görülmektedir. Oluşan bu farktan hareketle deney grubundaki öğrencilerin yazılı anlatımlarında kontrol grubundaki öğrencilerden daha fazla sayıda zarf kullandıkları 
söylenebilir. Bu sonucun istatiksel açıdan anlamlı olup olmadığını belirlemek için yapılan $t$ testine göre de deney ve kontrol grupları arasında anlamlı bir farklılığın bulunduğu tespit edilmiştir $(0.00<0.05)$. Bu durumda, deney grubunda kullanılan öğretim materyalleri ile zarfları öğrenen öğrencilerin kontrol grubundaki öğrencilere göre zarfları yazma becerisinde daha etkili kullandıkları iddia edilebilir. Yapılan t testi sonucunda deney ve kontrol grupları arasında ortaya çıkan anlamlı farklılığın yazılı anlatım sırasında kullanılan zarf sayısı üzerindeki etkisinin ne ölçüde olduğuna karar verebilmek için etki büyüklüğü değerleri hesaplanmıştır. Buna göre $d$ : 2.07, g:2.02 olarak tespit edilmiştir. Hesaplanan etki büyüklüğü değerlerine göre zarflar konusundaki öğretimin yazılı anlatımda kullanılan zarf sayıları üzerinde "çok büyük" etkiye sahip olduğu belirlenmiştir.

\section{3. Üçüncü Amaca iliş̧kin Bulgular}

$\mathrm{Bu}$ araştırma çerçevesinde veri toplama aracı olarak kullanılan yazılı anlatım kâğıtlarında deney ve kontrol grubundaki öğrencilerin hangi zarfları ne sıklıkla kullandıkları da incelenmiştir. Bulgulara göre deney grubundakiler bir metin boyunca toplamda 220 kez, kontrol grubundakiler ise 116 kez zarf görevindeki bir kelimeyi cümle içinde kullanmışlardır (T: 336). Buna göre deney ve kontrol grubu arasında deney grubu lehine 104 kullanımlık bir fark oluşmuştur. Aşağıdaki tabloda deney ve kontrol grubunun yazılı anlatım kâğıtlarında tespit edilen zarflar ve bunlardan en sık kullanılan 20 tanesi yer almaktadır:

Tablo 10: Deney ve Kontrol Grubundaki Öğrencilerin Kullandıkları Zarflar ve Sıklıkları

\begin{tabular}{|c|c|c|c|c|c|c|c|}
\hline Zarf & Grup & $f$ & $\%$ & Zarf & Grup & $f$ & $\%$ \\
\hline \multirow{2}{*}{ Çok } & Deney & 31 & 9.22 & \multirow{2}{*}{ iyice } & Deney & 9 & 2.67 \\
\hline & Kontrol & 21 & 6.25 & & Kontrol & 0 & 0 \\
\hline \multirow{2}{*}{ Sonra } & Deney & 24 & 7.14 & \multirow{2}{*}{ Fazla } & Deney & 6 & 1.78 \\
\hline & Kontrol & 15 & 4.46 & & Kontrol & 2 & 0.59 \\
\hline \multirow{2}{*}{ Önce } & Deney & 14 & 4.17 & \multirow{2}{*}{ Geri } & Deney & 4 & 1.19 \\
\hline & Kontrol & 7 & 2.08 & & Kontrol & 3 & 0.89 \\
\hline \multirow{2}{*}{ Orada } & Deney & 13 & 3.87 & \multirow{2}{*}{ Mutlaka } & Deney & 6 & 1.78 \\
\hline & Kontrol & 6 & 1.78 & & Kontrol & 1 & 0.29 \\
\hline \multirow{2}{*}{ Biraz } & Deney & 10 & 2.97 & \multirow{2}{*}{ Eskiden } & Deney & 5 & 1.48 \\
\hline & Kontrol & 7 & 2.08 & & Kontrol & 1 & 0.29 \\
\hline \multirow{2}{*}{ Burada } & Deney & 9 & 2.67 & \multirow{2}{*}{ Güzelce } & Deney & 6 & 1.78 \\
\hline & Kontrol & 6 & 1.78 & & Kontrol & 0 & 0 \\
\hline \multirow{2}{*}{ Bazen } & Deney & 9 & 2.67 & \multirow{2}{*}{ Sonunda } & Deney & 6 & 1.78 \\
\hline & Kontrol & 4 & 1.19 & & Kontrol & 0 & 0 \\
\hline \multirow{2}{*}{ Her zaman } & Deney & 6 & 1.78 & \multirow{2}{*}{ Tekrar } & Deney & 5 & 1.48 \\
\hline & Kontrol & 5 & 1.49 & & Kontrol & 1 & 0.29 \\
\hline \multirow{2}{*}{ Sadece } & Deney & 8 & 2.38 & \multirow{2}{*}{ Ara sıra } & Deney & 4 & 1.48 \\
\hline & Kontrol & 2 & 0.59 & & Kontrol & 1 & 1.19 \\
\hline \multirow{2}{*}{ Hiç } & Deney & 8 & 2.38 & \multirow{2}{*}{ Pek } & Deney & 5 & 1.49 \\
\hline & Kontrol & 1 & 0.29 & & Kontrol & 0 & 0 \\
\hline
\end{tabular}

Tablo incelendiğinde öğrencilerin cümlelerinde en çok zaman (8) zarflarına başvurduklarını daha sonra sırasıyla durum (5), miktar (4) ve yer-yön (3) zarflarını kullandıkları görülmektedir. Deney grubunun yazılı anlatım kâğıtlarında tespit edilen zarflar ele alındığında öğretim sürecinde yer alan zarflar ile öğrencilerin yazılarında kullandıkları zarflar arasında bir uyum olduğu göze çarpmaktadır. Yukarıdaki listede bulunan 20 farklı zarfın tamamı deney grubundaki öğrenciler tarafından değişik sıklıklarda kullanılmıştır. Kontrol grubundaki öğrenciler ise deney grubuna oranla daha az sıklıkta olmakla birlikte listedeki zarflarından 16 tanesini yazılı anlatım sırasında kullanmıştır. En sık kullanılan 20 zarf arasından kontrol grubunun yazılı anlatımlarında hiç kullanılmadığı belirlenen 4 adet zarf bulunmaktadır. 


\section{SONUÇ, TARTISSMA VE ÖNERILER}

Araştırma sonuçlarına göre deney ve kontrol gruplarında yer alarak zarfları öğrenen öğrencilere uygulanan başarı testinde, araştırmacı tarafından geliştirilen materyallerle bu süreci tamamlayan öğrencilerin sontest puanlarının öğretim seti ile eğitim alan kontrol grubu öğrencilerinin puanlarından daha yüksek olduğu ve gruplar arasında oluşan bu farkın anlamlı olduğu ortaya çıkmıştır. Bu bulgu geliştirilen öğretim materyallerinin deney grubundaki öğrencilerin zarflar konusundaki akademik başarı üzerinde önemli bir etkisinin olduğunu göstermektedir. Nitekim gruplar arasında oluşan puan farkının başarı üzerindeki etkisi istatiksel olarak hesaplandığında bağımsız değişkenin başarı üzerinde oldukça yüksek düzeyde etkisi olduğu tespit edilmiştir (d: 1.33 ve $g: 1.30$ ). Bu sonuç deney grubunun eğitim sürecinde kullanılan materyallerin zarflar konusunda akademik başarıyı olumlu yönde etkileyip artırdığını göstermektedir. Buradan hareketle geliştirilen öğretim materyalinin öğretim sürecinde kullanılabilecek yetkinlikte ve nitelikte olduğu, öğrencilere zarflar konusunda dil setlerinde yer alan etkinliklerle yapılan öğretimden daha fazla yarar sağladığı söylenebilir.

Araştırmada elde edilen bir diğer sonuca göre deney grubunda yer alan öğrencilerin yazılı anlatımlarında kontrol grubu öğrencilerine göre daha çok sayıda zarf kullandıkları belirlenmiştir. Iki grup arasında kullanılan zarf sayısı bakımından oluşan farklılığın istatiksel olarak anlamlı olduğu da tespit edilmiş ve bu farkın etki değerinin akademik başarı testi bulgularıyla örtüşür biçimde oldukça yüksek seviyede olduğu belirlenmiştir (d: 2.07 ve g: 2.02). Bu sonuç araştırmacı tarafından geliştirilen öğretim materyaliyle yapılan eğitimin öğrencilerin yazma becerilerinin gelişimine zarfları kullanabilme becerisi bakımından katkı sağladığını göstermektedir. Bu veri geliştirilen materyalin dil bilgisi - yazma becerisi etkileşimini sağlamada etkili ve işlevsel olduğunu, başka bir deyişle materyalin bu niteliği taşıdığını ortaya çıkarmıştır. Kontrol grubu öğrencilerinin de aynı konuyu öğrenmesine rağmen deney grubunda yer alan öğrencilerin yazarken daha çok zarf kullandıkları dikkate alındığında öğretim materyallerinin farkındalık oluşturmada ve öğrenilen dil bilgisi konusunun dil becerilerine aktarılmasında oldukça başarılı olduğu anlaşılmaktadır. Bu kanıttan yola çıkarak materyallerin zarflar konusunda diğer dil becerileri üzerinde de olumlu bir etki oluşturacağı şeklinde bir değerlendirme yapılabileceği düşünülmektedir.

Araştırma kapsamında etkisi araştıılan materyallerle yapılan öğretimden hem akademik başarı hem de yazma becerisi bakımından daha başarılı sonuç elde edilmesinin aşağıdaki nedenlerle açıklanabileceği düşünülmektedir:

* Materyallerin birden fazla duyuya hitap edecek şekilde tasarlanmış olması

* Animasyonların zarfların anlam ve işlevlerinin anlaşılmasını kolaylaştırması

* Materyallerde örnek olarak seçilen zarfların sıklık ve seviye bakımından yerinde olması

* Öğrenilenlerin pekiştirilmesine ve özellikle yazma becerisine aktarılmasına yardım edecek nitelikte konu sonu alıştırmalarının verilmesi

* Materyalin konusu ile öğretime ayrılan sürenin uyumu ve öğretim süresinin yeterli olması

* Materyallerde kullanılan görsel ve dilsel düzenin zarflar konusunda farkındalık oluşturmada etkili ve başarılı olması

Bahsedilen bu hususlar aynı zamanda materyal geliştirme sürecinde dikkat edilmesi gerekenlere de ışık tutmaktadır. Daha açık bir ifadeyle; dil öğretiminde kullanılmak üzere hazırlanacak materyallerin birden fazla duyuya hitap etmesi, öğretilecek konunun anlam ve işlev yönünü hesaba katması, öğrenci seviyesine uygun olması, öğrenilenlerin pekiştirilmesine ve diğer becerilere aktarılmasına imkân verecek özellikte olması, öğretim süresi ile uyumlu 
olması ve öğretilen konuda farkındalık oluşturabilmesi gerekmektedir. Bu hususlar dikkate alınarak geliştirilen materyallerin öğrenci başarııını artıracağı düşünülmektedir.

Sonuç olarak bu araştırmada; yabancı dil olarak Türkçe öğretiminde zarfların B1 seviyesinde öğretilmesinin yerinde olduğu teyit edilmiş, dil bilgisi konularının dil becerileri üzerinde yazma becerisi özelinde etkili olduğu ortaya koyulmuş ve geliştirilen öğretim materyallerinin gerçek öğretim sırasında kullanılabilecek nitelikte olduğu belirlenmiş; ayrıca zarflar konusunun ölçülmesinde kullanılabilecek geçerlilik-güvenirlik çalışmaları yapılmış bir başarı testi de alanyazına kazandırılmıştır.

Bu araştırmanın bulgu ve sonuçlarından hareketle şu önerilerde bulunulabilir:

* Yabancı dil eğitiminde dil bilgisi konusunda yapılan öğretim ve uygulanan etkinlikler mutlaka yazma becerisini geliştirecek şekilde olmalıdır.

* Yabancı dil olarak Türkçe öğretimi için geliştirilen materyaller teoride bırakılmayarak mutlaka öğretim süreci içerisinde denenmeli, eğer olumlu sonuç elde edilirse öğretim seti hazırlayanlar ve okutmanlar tarafından dikkate alınarak Türkçenin yabancı dil olarak öğretim sürecine dâhil edilmelidir.

* Bu araştırmada etkisi denenen materyallerin öğretim setinde yer alan etkinliklere göre daha yüksek bir başarı elde edilmesini sağladığı göz önüne alındığında dil öğretim setlerindeki zarflar konusu yeniden ele alınmalı ve bu konudaki öğretim etkinlikleri öğrenci yararı gözetilerek iyileştirilmelidir.

* Bilinçli ve amaçlı şekilde geliştirilmiş bir materyal öğretime eklendiğinde öğrenci başarısının arttığı görülmektedir. Bu nedenle yabancı dil olarak Türkçe öğretiminde görev alan okutmanların yalnızca dil öğretim setleriyle yetinmemesi, mümkün olduğunca bilimsel yöntemlerle geliştirilen öğretim materyallerini de kullanması gerekmektedir.

* Dil öğretiminde hangi konuda nasıl bir eksiklik olduğu ve bunun nasıl giderilebileceği en iyi bu süreci yürüten öğreticiler tarafından bilinmektedir. Bu nedenle Türkçenin yabancı dil olarak öğretiminde tecrübesi olan eğitimcilerin de öğretim materyali geliştirme çabası içinde olması önem arz etmektedir. Bu doğrultuda Türkçe öğretimi alanında görevli olanlara hizmet içi eğitim verilmeli ve materyal geliştirme çalışmaları yapmaları ilgili kurumlarca teşvik edilmelidir.

* Yabancı dil olarak Türkçe öğretimi için geliştirilen materyallerin yetkinliği ve başarı üzerindeki etkisi ile ilgili daha çok araştırma yapılmalı, elde edilecek sonuçlar karşılaştırılarak bu konuda bilgi birikimi oluşması sağlanmalıdır.

\section{KAYNAKLAR}

Aksu, C. (2014). Yabancı Dil Olarak Türkçede -Dır Biçimbiriminin Öğretimi Üzerine Ders Malzemesi Hazırlama (Yayımlanmamış Yüksek Lisans Tezi). İmir: Dokuz Eylül Üniversitesi Eğitim Bilimleri Enstitüsü, İzmir.

Banguoğlu, T. (1986). Türkçenin Grameri. Ankara: Türk Dil Kurumu Yayınları.

Bilgegil, K. (1984). Türkçe dil bilgisi. İstanbul: Dergâh Yayınları.

Camkıran, Ö. (2007). Yabancı Dil Olarak Türkçe Öğrenenler Için Şimdiki Zamanın Metinlerle Öğretimi (Yayımlanmamış Yüksek Lisans Tezi). Dokuz Eylül Üniversitesi, Eğitim Bilimleri Enstitüsü, İzmir. 
Cohen, J. (1988). Statistical power analysis for the behavioral sciences (2nd ed.). New Jersey: Lawrence Erlbaum.

Düzenli, S. (2008). Türkçede Ortaçlaştırma Belirticilerinin Öğretimine Yönelik Ders Malzemesi Hazırlama (Yayımlanmamış Yüksek Lisans Tezi). Dokuz Eylül Üniversitesi, Eğitim Bilimleri Enstitüsü, İzmir.

Eker, S. (2011). Çağdaş Türk dili. Ankara: Grafiker Yayınları.

Ergin, M. (2008). Türk dil bilgisi. İstanbul: Bayrak Basım/Yayın/Dağıtım.

Gencan, T. N. (2001). Dilbilgisi. Ankara: Ayraç Yayınevi.

Gülensoy, T. (2010). Türkçe el kitabı. Ankara: Akçağ Yayınları.

Hacıömeroğlu, M. S. (2007). Yabancı Dil Olarak Türkçe Öğrenenler İçin Kiplik Öğretimi Üzerine Materyal Geliştirme (Yayımlanmamış Yüksek Lisans Tezi). Dokuz Eylül Üniversitesi, Eğitim Bilimleri Enstitüsü, İzmir.

Hedges, L. (1981). Distribution Theory for Glass's Estimator of Effect Size and Related Estimators. Journal of Educational Statistics. Vol. 6, No. 2 (Summer, 1981), pp. 107-128.

Hengirmen, M. (1998). Türkçe Temel Dilbilgisi. Ankara: Engin Yayınları.

Hopkins, W. G: (1997). New view of statistics. 10.06.2017 tarihinde http://www.sportsci.org/resource/stats/effectmag.html adresinden erişilmiştir.

Karaağaç, G. (2012). Türkçenin dil bilgisi. Ankara: Akçağ Yayınları.

Karahan, L. (2005). Türkçede sözdizimi. Ankara: Akçağ Yayınları.

Karasar, N. (2010) Bilimsel araştırma yöntemi. Ankara: Nobel Yayın Dağıtım.

Kasapoğlu, A. (2012). Yabana dil olarak Türkçe öğrenenler için ulaçların (zarf- fiillerin) öğretimine yönelik materyal geliştirme (Yayımlanmamış Yüksek Lisans Tezi). Dokuz Eylül Üniversitesi, Eğitim Bilimleri Enstitüsü, İzmir.

Korkmaz, C. B. (2014). Yabancı dil olarak Türkçenin öğretiminde birleşik zamanlı fiillerin öğretimi ve öğretimine yönelik etkinlik oluşturma. (Yayımlanmamış Yüksek Lisans Tezi). Gazi Üniversitesi, Eğitim Bilimleri Enstitüsü, Ankara.

Korkmaz, Z. (2009). Türkiye Türkçesi Grameri: Şekil Bilgisi. Ankara: Türk Dil Kurumu Yayınları.

Memiş, M. R. (2014). Yabancı Dil Olarak Türkçe Öğrenenler Iç̧in Zarfların Öğretimine Yönelik Materyal Geliştirme (Yayımlanmamış Yüksek Lisans Tezi). Ondokuz Mayıs Üniversitesi, Eğitim Bilimleri Enstitüsü, Samsun.

Özgen, M. (2010). Türkçe Soru Tümcelerinin Öğretimi (Yayımlanmamış Yüksek Lisans Tezi). Dokuz Eylül Üniversitesi, Eğitim Bilimleri Enstitüsü, İzmir.

Öztürk, K. Ö. (2012). Türkçedeki Tanıtsallık Belirten Sıfatların ve Belirteçlerin Yabancı Dil Olarak Türkçe Derslerinde Öğretimi (Yayımlanmamış Yüksek Lisans Tezi). Dokuz Eylül Üniversitesi, Eğitim Bilimleri Enstitüsü, İzmir.

TDK (2011). Türkçe Sözlük. Ankara: Türk Dil Kurumu Yayınları.

Turan, F. (1998). Türkçede Zarflar Üzerine. Folkloristik: Prof. Dr. Dursun Yıldırım Armağanı. s. 301-306. Ankara.

Sarıçiyil, F. (2008). İstek ve Emir Kiplerinin Öğretimi (Yayımlanmamış Yüksek Lisans Tezi). Dokuz Eylül Üniversitesi, Eğitim Bilimleri Enstitüsü, İzmir. 
Sülüşoğlu, B. (2008). İşe Dayalı Dil Öğretim Malzemelerinin Türkçe'nin Yabancı Dil Olarak Öğretiminde Uygulanması (Yayımlanmamış Yüksek Lisans Tezi). Dokuz Eylül Üniversitesi, Eğitim Bilimleri Enstitüsü, İzmir.

Ünlücömert, N. (2010) -m/ş Biçim Biriminin Farklı İşlevlerinin Bilinç Uyandırma Teknikleriyle Öğretimine Yönelik Malzeme Oluşturma (Yayımlanmamış Yüksek Lisans Tezi). Dokuz Eylül Üniversitesi, Eğitim Bilimleri Enstitüsü, İzmir.

Vardar, B. (2002). Açıklamalı Dilbilim Terimleri Sözlüğü. İstanbul: Multilingual.

Yolcusoy, Ö. (2008). Türkçe Koşullu Yapıların Öğretimine Yönelik Malzeme Tasarımı (Yayımlanmamış Yüksek Lisans Tezi). Dokuz Eylül Üniversitesi, Eğitim Bilimleri Enstitüsü, İzmir. 


\section{Ek: Zarflar Konusunda Hazırlanan Başarı Testi}

Aşağıdaki sorularda verilen boşluklara kalın yazılmış olan kelime getirildiğinde anlamsız/mantıksız bir cümle oluşturan cümlenin yer aldığı seçeneği işaretleyiniz.

1) Aşağıda bulunan cümlelerdeki boşlukların hangisine "güzel" kelimesi getirilemez?

A) Dün akşamki partide bir kız ile tanıştım.

B) Doğum günümde annem bana çok bir saat hediye etti.

C) Arkadaşımın yeni kıyafetinin rengi en sevdiğim renk olan mavi.

D) Yemeklerin tadına henüz bakmadım ama yemekler çok görünüyor.

2) Aşağıda bulunan cümlelerdeki boşlukların hangisine "hızlı" kelimesi getirilemez?

A) Ankara ile Eskişehir arası tren ile sadece bir saat sürüyor.

B) Tatilde zaman çok or. Tatilin bu kadar çabuk bitmesine inanamıyorum.

C) Yabancı dil öğretmenimiz o kadar konuşuyor ki ne söylediğini anlayamıyorum.

D) Havalar çok sıcak. Bu sıcaklar ne zaman bitecek merak ediyorum.

3) Aşağıda bulunan cümlelerdeki boşlukların hangisine "yeni" kelimesi getirilemez?

A) Pideler fırından çıktı. Lütfen soğuması için biraz bekleyin.

B) Fenerbahçe dün yine yenildi. Ne zaman maç kazanacaklarını merak ediyorum!

C) arabanız hayırlı olsun! Güle güle kullanın!

D) Ahmet'in kaza yaptığını öğrendik. Bugün hastaneye onu ziyarete gideceğiz.

Aşağıdaki cümlelerin karşısında bulunan kelimeleri verilen boşluklardan uygun olanına yerleştiriniz.

4) Sabah otobüsü kaçırdığım için derse kaldım. (geç)

5) İnsan aynı hatayı yapmamalı. Hatalarından ders çıkarmalı. (tekrar)

6) Güzel bir haber $\mathrm{m}$ aldın? çok görünüyorsun. (mutlu)

Aşağıdaki cümlelerin karşısında bulunan kelimeleri anlamlı olacak şekilde zarf görevinde kullanınız.

7) Eğer sınavını bitirdiysen dışarı çıkabilirsin. (sessiz)

8) Lütfen bana kızma! Seninle ayrılmak istemiyorum. (kötü)

9) Merve çok zeki bir öğrenci. En zor soruların çözümünü bile bulur. (kolay)

10) Benden korkmana gerek yok. Ne söylemek istiyorsan söyle! (açık)

11) O vazoyu sakın yere düşürme. Lütfen onu masanın üstüne koy. (yavaş)

12) Yurtdışında yaşayan halamla neredeyse iki yıldır hiç görüşmedik. Birbirimizi görmeyeli bir süre geçti. (uzun)

$\begin{array}{llllll}\text { Aniden } & \text { Çabucak } & \text { Hep birlikte } & \text { Iyice } & \text { Erken } & \text { Sonunda } \\ \text { Henüz } & \text { Sık sık } & \text { Ileri } & \text { Dışarı } & \text { Uzak } & \text { Yukarı }\end{array}$

Yukarıdaki kutucuklarda bulunan kelimeleri aşağıdaki cümlelerde yer alan boşluklardan anlamca en uygun olan boşluğa yerleştiriniz. 
13) Geçen hafta sınıf arkadaşlarımızla İstanbul'a gezmeye gittik. Hem gezi hem de yolculuk çok güzel geçti. Yol boyunca şarkılar söyledik ve çok eğlendik.

14) Bir haftadır süren fırtına nihayet durdu. Bir hafta boyunca fırtınanın geçmesini bekleyen insanlar da evlerinden çıktılar ve ihtiyaçlarını karşılamak için marketlere koştular.

15) Dün akşamki maçta ayağı kırılan futbolcu bir yıl süreyle sahalardan kalacak. Bu sakatlık hem onun için hem de takım için çok büyük bir kayıp oldu.

16) Ne kadar çabalarsam çabalayayım sabahları kalkamıyorum. Bu yüzden de derslere hep geç kalıyorum. Sanırım bu sorunu çözmek için artık doktora gideceğim.

17) Akşamüstü batıran yağmur insanları hazırlıksız yakaladı. Sağanak yağmur nedeniyle trafik de alt üst oldu.

18) Kardeşimin bağışıklık sistemi çok güçsüz ve vücudu mikroplara karşı oldukça dayanıksız. Bu yüzden de hasta oluyor.

19) Yıllardır hayalini kurduğum arabayı aldım. O kadar mutluyum ki size anlatamam. Hayallerim gerçek oldu.

20) Hava oldukça serin. Bu yüzden dışarı çıkmadan önce saçlarını kurulamalısın. Yoksa üşütüp hasta olursun. Benden söylemesi...

21) Yaptığım iş başvurusundan bir haber gelmedi ama bu işe alınacağım konusunda hala umudumu yitirmedim.

22) Arkadaşım topu o kadar oradan nasıl alacağız, bilmiyorum. fırlattı ki top evin çatısında kaldı. Şimdi topu

23) Bu akşam bize misafir gelecekmiş. Eşim şimdi arayıp haber verdi. Evi temizleyip misafirler için pasta yapacağım. Bu işleri yetiştirmek için acele etmem lazım.

24) Buraya park etmek yasak. Lütfen arabanızı biraz park edin!

Aşağıdaki cümlelerde soruya göre boş bırakılan yerlere getirilebilecek veya getirilmeyecek olan en uygun kelimeyi işaretleyiniz.

25) "içeride devam eden bir toplantı var. Lütfen bırakılan yere aşağıdaki kelimelerden hangisinin getirilmesi daha uvgundur?
A) Yine
B) Biraz
C) Bir süre
D) Sadece

26) "Asitli içecekler ve hazır gıdalar insan sağlığı için zararlı. Doktorlar mümkün olduğunca bu tür yiyecek ve içeceklerden uzak durmak gerektiğini söylüyorlar." cümlesinde boş bırakılan yere aşağıdaki kelimelerden hangisi getirilemez?
A) Oldukça
B) Son derece
C) Ne kadar
D) Epey

27) "Toplu bir şekilde insanların bulunduğu kafe, restoran, toplantı salonu gibi yerlerde sigara içmek yasaklandı. Bundan sonra sigara içenlere para cezası verilecek." Cümlesinde boş bırakılan yere aşağıdaki kelimelerden hangisi getirilemez?
A) Nihayet
B) Tamamen
C) Artık
D) Daima

28) "Köpeğim tasması biranda elimden kurtuldu ve köpeğim bu tarafa doğru kaçtı. Acaba kelimelerden hangisi getirilemez? gittiğini gördünüz mü?” cümlesinde boş bırakılan yere aşağıdaki
A) Neyle
B) Nereye
C) Hangi yöne
D) Ne tarafa 
Yabancı Dil Olarak Türkçe Öğretimi Sürecinde Kullanılmak Üzere Geliştirilen Dil Bilgisi Materyallerinin

29) "Bu bulmacadaki sorular çok zor. Bulmacayı tamamlayacağımı bilmiyorum." cümlesinde boş bırakılan yere aşağıdaki kelimelerden hangisinin getirilmesi daha uygundur?
A) Kiminle
B) Nasıl
C) Neden
D) Ne biçim

30) "Babamın bana kargoyla gönderdiği kutunun içinde olduğunu çok merak ediyorum. Umarım kargo bir an önce teslim edilir." cümlesinde boş bırakılan yere aşağıdaki kelimelerden hangisinin getirilmesi daha uygundur?
A) Nerede
B) Ne kadar
C) Kim
D) $\mathrm{Ne}$ 


\section{SUMMARY}

Due to meaning based grammar subject, adverbs are irreplaceable component of phrases. They play an important role in establishing healthy and effective communication because adverbs explain and clarify meaning in phrase at all points. In this respect, it can be said that adverbs have key mission in fulfilling communicational function of language. Nowadays, the ideas that language teaching should be carried out meaning based and communication oriented; and grammar subjects should be selected in this direction too, are accepted widely. When viewed from this aspect, we believe that learning adverbs in foreign language contributes individuals to clarify meanings when they communicate, helps them to expand their vocabularies and to develop language skills directly or indirectly. Due to the explained reasons above, adverbs should take a part in language learning and teaching process.

When course books used in Turkish teaching as foreign language process, are viewed, it is seen that adverbs take part in instruction yet it is not enough in terms of quality and quantity. Unfortunately, mentioned material deficiency on adverbs can be observed in many grammar topics when it comes to Turkish teaching. Therefore, researchers started to develop grammar teaching materials for process of Turkish teaching as foreign language recently in order to fill the gap. When this studies which aim to provide teaching materials needed for both instructing grammar topics and improving language competences in the process of teaching Turkish as foreign language, are analyzed, the most important deficiency is that developed materials have not been tested in terms of functionality, in other words, have not been confirmed with regard to influence on achievement by using these materials in real teaching process. In this research basing upon mentioned problem, it is aimed to find out effectiveness, efficiency and influence on achievement of teaching materials developed for using in teaching Turkish as foreign language. With limited words in the sense of this study's scope, the purpose of this research is to present whether materials enriched with animations in the topic of adverbs have impact on academic achievement of Turkish learners as foreign language or not and variance between groups happens with regard to use of what is learnt in writing competence at the end of implementation or not. In accordance with these main goals, it is tried to answer questions below:

1) Is there any significant difference between experiment and control groups' mean scores of the posttest?

2) Is there any significant difference between experiment and control groups' number of adverbs that learners use in their writings?

3) What are the frequent adverbs that learners of experiment and control groups use?

This research designed with control group posttest experimental model, carried out 32 (16 experimental, 16 control) Turkish language learners who are in 2 different B1 level class selected randomly. According to research results; posttest scores of learners in experimental group who learn adverbs with the materials prepared by researcher are higher than points of students in control group who went with the course book on adverbs and this variation between experimental and control groups is significant. When effect of score variation occurred between groups on achievement is calculated, it is determined that independent variable has quite big impact on success. In accordance with another outcome from research; it is detected that learners in experimental group used more adverbs than students in control group as writing. These results show that materials used during instruction of experimental group, affect academic achievement positively in the topic of adverbs and enhance it; instruction via the materials prepared by researcher, contribute to improvement of learners' writing competence in point of ability to use adverbs. 